\title{
Ensuring energy security in the Siberian Federal District: analysis of the situation and the main trends
}

\author{
Elena Smirnova, ${ }^{1, *}$ \\ ${ }^{1}$ Melentiev Energy Systems Institute, 130 Lermontov str., Irkutsk, Russia
}

\begin{abstract}
This paper presents an assessment of the level of energy security of the subjects of the Russian Federation located on the territory of the Siberian Federal District. The approach to the assessment is based on the use of the monitoring and indicative analysis of energy security developed at ESI SB RAS. As a result, the main problems were identified with ensuring energy security in the regions, with a view to further developing ways to improve the situation in them.
\end{abstract}

\section{Introduction}

This paper presents the process of assessing the level of energy security of Russia subjects located on the territory of the Siberian Federal District. This assessment was carried out on the basis of the use of the monitoring apparatus and indicative analysis of energy security developed at ESI SB RAS. The main problems with ensuring energy security for individual regions are reflected, which is the basis for forming directions for improving the existing situation in the Siberian Federal District as a whole.

The tasks monitoring of Russia's ES and its regions are to identify the observed and expected processes, phenomena and parameters that determine the level and threats to energy security. At the same time, the identification process is based on a system of indicators that adequately describe the situation in one or another aspect of securing ES. Thus, the meaning and essence of monitoring and indicative analysis consist in displaying information on the degree of implementation of ES threats using an indicator system when comparing the numerical values of these indicators with their threshold values.

Energy security - the state of protection of citizens, society, the state, the economy from the threat of a deficit in providing their energy needs with economically accessible energy resources of acceptable quality, from threats of disrupting the continuity of energy supply. In fact, at any level, energy security is the balance of energy supply and demand or the lack of energy deficit. The reasons for the imbalance can be found both in the state of the objects of the fuel and energy complex and in adverse changes in natural, political and economic conditions. Comprehensive assessment of potential threats of ES, which are imminent within the fuel and energy complex and arising from outside due to changes in external energy conditions, is rather difficult to obtain. At the same time, an assessment of the level of the region's ES, determined by the state of the fuel and energy complex objects in this region and related federal energy systems, can be found using numerically evaluated indicative indicators, using the data [1] on the relevant parameters of the objects and the processes recorded.

An indicative assessment of the level of energy security of a specific region of the country is proposed to implement three, largely interrelated, blocks of indicators: production and resource provision of the region's fuel and energy supply system; reliability of the fuel and energy supply system in the region; state of the basic production assets energy systems in the region.

On the first two blocks, specific indicators can be distributed quite arbitrarily, since they are directly or indirectly related to each other.

The composition of the most important indicative indicators of energy security at the regional level, structured by blocs, is shown in Table. 1 .

With the use of a methodology specially developed at ESI SB RAS, which allows taking into account the peculiarities of energy supply in individual regions [1-3], threshold values of indicative indicators for all RF subjects were expertly determined.

\section{Results of the conducted indicative analysis}

When performing the study, the values of indicators by region were quantitatively correlated with their threshold values adopted in [3]. This allowed us to assess the qualitative state of each indicator in the relevant subject of analysis. As an example, the results of such work for the regions of the Siberian Federal District are presented below (Tables 2-5). 
Table 1. Composition of the most important indicators of regional energy security.

\begin{tabular}{l}
\hline 1. Block of production and resource provision of the region's \\
fuel and energy supply system \\
\hline 1.1. The ratio of the total available capacity of the region's \\
power plants to the maximum electric load of consumers on its \\
territory. \\
1.2. The ratio of the amount of available capacity of power \\
plants and the throughput of interconnections between the \\
region and neighboring consumers to the maximum electric \\
load on its territory. \\
1.3. Possibilities to meet the needs for primary energy from the \\
region's own sources. \\
\hline 2. The block of reliability of fuel and energy supply of the \\
region \\
\hline 2.1. The share of the dominant resource in the total primary \\
energy consumption in the region. \\
2.2. The share of the largest power plant in the installed electric \\
capacity of the region. \\
2.3. The level of potential supply of demand for fuel in the \\
conditions of a sharp cooling (10\% consumption of \\
consumption) in the region. \\
\hline 3. Block of the state of basic production assets energy systems \\
in the territory of the region \\
\hline 3.1. Degree of depreciation of the basic production assets in the \\
energy sector of the region. \\
3.2. The ratio of the average annual input of installed capacity \\
and reconstruction of power plants in the region over the last $5-$ \\
year period to the established capacity of the region. \\
\hline
\end{tabular}

Table 2. Characteristics of the status of indicators in the territory of the subjects of the Siberian Federal District for the block of production and resource provision of the fuel and energy supply system for 2012, 2016

\begin{tabular}{|c|c|c|c|c|c|c|c|}
\hline \multirow{3}{*}{$\begin{array}{c}\text { Indi } \\
\text { cato } \\
\text { r }\end{array}$} & \multirow{3}{*}{$\begin{array}{c}\text { Dim } \\
\text { ensi } \\
\text { on }\end{array}$} & \multicolumn{2}{|c|}{$\begin{array}{l}\text { The threshold } \\
\text { values of the } \\
\text { indicator }\end{array}$} & \multicolumn{4}{|c|}{$\begin{array}{l}\text { The meaning and status of } \\
\text { the indicator, year }\end{array}$} \\
\hline & & \multirow{2}{*}{$\begin{array}{l}\mathrm{N} \\
3 \\
\end{array}$} & \multirow{2}{*}{$\begin{array}{l}\mathrm{C} \\
4\end{array}$} & \multicolumn{2}{|c|}{2012} & \multicolumn{2}{|c|}{2016} \\
\hline & & & & 5 & 6 & 7 & 8 \\
\hline \multicolumn{8}{|c|}{ Altai region } \\
\hline 1.1 & ед. & 0,5 & 0,3 & 0,74 & $\mathrm{~N}$ & 0,72 & $\mathrm{~N}$ \\
\hline 1.2 & ед. & 1,5 & 1,2 & 3,03 & $\mathrm{~N}$ & 3,1 & $\mathrm{~N}$ \\
\hline 1.3 & $\%$ & 60 & 40 & 1,55 & $\mathrm{C}$ & 1,75 & $\mathrm{C}$ \\
\hline \multicolumn{8}{|c|}{ Kemerovo Region } \\
\hline 1.1 & ед. & 0,5 & 0,3 & 0,85 & $\mathrm{~N}$ & 1,01 & $\mathrm{~N}$ \\
\hline 1.2 & ед. & 1,5 & 1,2 & 2,27 & $\mathrm{~N}$ & 2,55 & $\mathrm{~N}$ \\
\hline 1.3 & $\%$ & 40 & 20 & 5,88 & $\mathrm{~N}$ & 1052 & $\mathrm{~N}$ \\
\hline \multicolumn{8}{|c|}{ Novosibirsk region } \\
\hline 1.1 & ед. & 0,5 & 0,3 & 1,03 & $\mathrm{~N}$ & 1,03 & $\mathrm{~N}$ \\
\hline 1.2 & ед. & 1,5 & 1,2 & 2,18 & $\mathrm{~N}$ & 2,18 & $\mathrm{~N}$ \\
\hline 1.3 & $\%$ & 40 & 20 & 33,7 & $\mathrm{~N}$ & 40,4 & $\mathrm{~N}$ \\
\hline \multicolumn{8}{|c|}{ Omsk Region } \\
\hline 1.1 & ед. & 0,5 & 0,3 & 0,84 & $\mathrm{~N}$ & 0,86 & $\mathrm{~N}$ \\
\hline 1.2 & ед. & 1,5 & 1,2 & 2,44 & $\mathrm{~N}$ & 2,46 & $\mathrm{~N}$ \\
\hline 1.3 & $\%$ & 40 & 20 & 48,3 & $\mathrm{~N}$ & 36,9 & $\mathrm{PC}$ \\
\hline \multicolumn{8}{|c|}{ Tomsk Region } \\
\hline 1.1 & ед. & 0,5 & 0,3 & 0,81 & $\mathrm{~N}$ & 0,77 & $\mathrm{~N}$ \\
\hline 1.2 & ед. & 1,5 & 1,2 & 2,76 & $\mathrm{~N}$ & 2,77 & $\mathrm{~N}$ \\
\hline 1.3 & $\%$ & 60 & 40 & 121 & $\mathrm{~N}$ & 294 & $\mathrm{~N}$ \\
\hline \multicolumn{8}{|c|}{ Krasnoyarsk region } \\
\hline 1.1 & ед. & 0,7 & 0,5 & 1,65 & $\mathrm{~N}$ & 2 & $\mathrm{~N}$ \\
\hline 1.2 & ед. & 1,5 & 1,2 & 2,39 & $\mathrm{~N}$ & 2,74 & $\mathrm{~N}$ \\
\hline 1.3 & $\%$ & 60 & 40 & 140 & $\mathrm{~N}$ & 142 & $\mathrm{~N}$ \\
\hline
\end{tabular}

\begin{tabular}{|c|c|c|c|c|c|c|c|}
\hline \multicolumn{1}{|c|}{ Irkutsk region } \\
\hline 1.1 & ед. & 0,7 & 0,5 & 1,58 & $\mathrm{~N}$ & 1,6 & $\mathrm{~N}$ \\
\hline 1.2 & ед. & 1,5 & 1,2 & 2,11 & $\mathrm{~N}$ & 2,13 & $\mathrm{~N}$ \\
\hline 1.3 & $\%$ & 60 & 40 & 122 & $\mathrm{~N}$ & 122 & $\mathrm{~N}$ \\
\hline \multicolumn{7}{|c|}{ The Republic of Khakassia } \\
\hline 1.1 & ед. & 0,7 & 0,5 & 2,85 & $\mathrm{~N}$ & 2,42 & $\mathrm{~N}$ \\
\hline 1.2 & ед. & 1,5 & 1,2 & 4,67 & $\mathrm{~N}$ & 4,28 & $\mathrm{~N}$ \\
\hline 1.3 & $\%$ & 60 & 40 & 557 & $\mathrm{~N}$ & 740 & $\mathrm{~N}$ \\
\hline \multicolumn{7}{|c|}{ Transbaikal region } \\
\hline 1.1 & ед. & 1,0 & 0,8 & 1,22 & $\mathrm{~N}$ & 1,19 & $\mathrm{~N}$ \\
\hline 1.2 & ед. & 1,5 & 1,2 & 1,6 & $\mathrm{~N}$ & 1,57 & $\mathrm{~N}$ \\
\hline 1.3 & \% & 60 & 40 & 266 & $\mathrm{~N}$ & 233 & $\mathrm{~N}$ \\
\hline \multicolumn{8}{|c|}{ The Republic of Buryatia } \\
\hline 1.1 & ед. & 0,5 & 0,3 & 1,31 & $\mathrm{~N}$ & 1,28 & $\mathrm{~N}$ \\
\hline 1.2 & ед. & 1,5 & 1,2 & 3,35 & $\mathrm{~N}$ & 3,19 & $\mathrm{~N}$ \\
\hline 1.3 & $\%$ & 60 & 40 & 49,6 & РC & 76,1 & $\mathrm{~N}$ \\
\hline \multicolumn{7}{|c|}{ Tyva Republic } \\
\hline 1.1 & ед. & 0,5 & 0,3 & 0,38 & РC & 0,22 & $\mathrm{C}$ \\
\hline 1.2 & ед. & 1,5 & 1,2 & 1,18 & $\mathrm{C}$ & 1,78 & $\mathrm{~N}$ \\
\hline 1.3 & $\%$ & 60 & 40 & 199 & $\mathrm{~N}$ & 240 & $\mathrm{~N}$ \\
\hline \multicolumn{8}{|c|}{ Altai Republic } \\
\hline 1.1 & ед. & 0,5 & 0,3 & 0 & $\mathrm{C}$ & 0,13 & $\mathrm{C}$ \\
\hline 1.2 & ед. & 1,5 & 1,2 & 0 & $\mathrm{C}$ & 0,13 & $\mathrm{C}$ \\
\hline 1.3 & $\%$ & 60 & 40 & 7,69 & $\mathrm{C}$ & 12,2 & $\mathrm{C}$ \\
\hline
\end{tabular}

Along with the qualitative assessment of the energy security level of the regions in 2016, in order to show some trends, information is provided on the qualitative assessment of the relevant indicators in 2012. As a result of analysing the data of the corresponding tables for the subjects of the Siberian Federal District, it is possible to briefly characterize the trends inherent in the energy sector from positions of requirements of power safety.

According to the first block of indicators, the situation is acceptable from the EB's point of view in practically all subjects of the Siberian Federal District.

The exception is the Republic of Altai, where the values of the indicators are in a crisis state (Table 2). Here you can note a low level of the maximum electrical load of consumers. But the situation slowly began to improve and for the period 2014-2016. Three solar power stations were commissioned with a total capacity of 15 MW (Kosh-Agach SES-1, 2, Ust-Kansky SES), and further new capacity inputs are planned.

In the Republic of Tuva in comparison with 2012. by 2016 the values of indicator 1.2 went into the range of acceptable values. In 2014. the throughput of intersystem connections was increased due to the modernization of substations (PS Kyzylskaya, SS Chadan) to $280 \mathrm{MW}$ of capacity, of which up to $100 \mathrm{MW}$ can be transferred to Western Mongolia. However, in general, the problem of energy deficit of the republic is not solved.

In addition, for the first block of indicators, in particular for indicator 1.3 , one can note the Altai Territory, the Republic of Altai with crisis values. Omsk region, where by 2016 . The situation has worsened due to a $20 \%$ decrease in the production of fuel oil over the past five years. In the Republic of Buryatia, on the contrary, the values of the indicators have moved into the region of acceptable, as a result of the development of a number of small coal deposits for local needs and an 
increase in the level of coal production by $30 \%$ over the past five years.

Satisfactory situation for the first block of indicators in the Republic of Khakassia. With sufficient margin, the maximum electrical load is ensured. Extraction of significant volumes of coal provides positive values of the indicator of supply with own primary energy. According to the second set of indicators, the situation in most of the regions is aggravated by an excessively high share of dominance of one of the imported resources (indicator 2.1, Table 3).

Table 3. Characteristic of the status of indicators in the territory of the subjects of the Siberian Federal District

for the fuel and energy supply reliability block

\begin{tabular}{|c|c|c|c|c|c|c|c|}
\hline \multirow{3}{*}{$\begin{array}{c}\text { Indicat } \\
\text { or } \\
\text { (dimen } \\
\text { sion - } \\
\% \text { ) } \\
1\end{array}$} & \multicolumn{3}{|c|}{$\begin{array}{l}\text { The threshold } \\
\text { values of the } \\
\text { indicator }\end{array}$} & \multicolumn{4}{|c|}{$\begin{array}{l}\text { The meaning and status of } \\
\text { the indicator, year }\end{array}$} \\
\hline & \multirow[t]{2}{*}{$\mathrm{N}$} & \multirow{2}{*}{$\begin{array}{c}\mathrm{PC} \\
3\end{array}$} & \multirow{2}{*}{$\begin{array}{l}\mathrm{C} \\
4\end{array}$} & \multicolumn{2}{|c|}{2012} & \multicolumn{2}{|c|}{2016} \\
\hline & & & & 5 & 6 & 7 & 8 \\
\hline \multicolumn{8}{|c|}{ Altai region } \\
\hline 2.1 & 40 & & 70 & 92,4 & $\mathrm{C}$ & 88,5 & $\mathrm{C}$ \\
\hline 2.2 & 50 & & 70 & 22,8 & $\mathrm{~N}$ & 24,2 & $\mathrm{~N}$ \\
\hline \multicolumn{8}{|c|}{ Kemerovo Region } \\
\hline 2.1 & 90 & $>90$ & & 83,5 & $\mathrm{~N}$ & 96,0 & $\mathrm{~N}$ \\
\hline 2.2 & 50 & & 70 & 25,8 & $\mathrm{~N}$ & 23,7 & $\mathrm{~N}$ \\
\hline \multicolumn{8}{|c|}{ Novosibirsk region } \\
\hline 2.1 & 40 & & 70 & 72,6 & $\mathrm{C}$ & 68,9 & $\mathrm{PC}$ \\
\hline 2.2 & 50 & & 70 & 39,4 & $\mathrm{~N}$ & 39,4 & $\mathrm{~N}$ \\
\hline \multicolumn{8}{|c|}{ Omsk Region } \\
\hline 2.1 & 40 & & 70 & 50,6 & $\mathrm{PC}$ & 54,3 & $\mathrm{PC}$ \\
\hline 2.2 & 50 & & 70 & 43,4 & $\mathrm{~N}$ & 42,8 & $\mathrm{~N}$ \\
\hline \multicolumn{8}{|c|}{ Tomsk Region } \\
\hline 2.1 & 90 & $>90$ & & 68,7 & $\mathrm{~N}$ & 62,9 & $\mathrm{~N}$ \\
\hline 2.2 & 50 & & 70 & 24,3 & $\mathrm{~N}$ & 27,7 & $\mathrm{~N}$ \\
\hline \multicolumn{8}{|c|}{ Krasnoyarsk region } \\
\hline 2.1 & 90 & $>90$ & & 73,5 & $\mathrm{~N}$ & 75,4 & $\mathrm{~N}$ \\
\hline 2.2 & 40 & & 50 & 39,2 & $\mathrm{~N}$ & 32,8 & $\mathrm{~N}$ \\
\hline \multicolumn{8}{|c|}{ Irkutsk region } \\
\hline 2.1 & 90 & $>90$ & & 76,5 & $\mathrm{~N}$ & 70,6 & $\mathrm{~N}$ \\
\hline 2.2 & 40 & & 50 & 34,1 & $\mathrm{~N}$ & 33,9 & $\mathrm{~N}$ \\
\hline \multicolumn{8}{|c|}{ The Republic of Khakassia } \\
\hline 2.1 & 90 & $>90$ & & 96,5 & $\mathrm{PC}$ & 96,5 & $\mathrm{PC}$ \\
\hline 2.2 & 40 & & 50 & 90,9 & $\mathrm{C}$ & 89,5 & $\mathrm{C}$ \\
\hline \multicolumn{8}{|c|}{ Transbaikal region } \\
\hline 2.1 & 90 & $>90$ & & 96,4 & $\mathrm{PC}$ & 98,1 & $\mathrm{PC}$ \\
\hline 2.2 & 30 & & 40 & 29,3 & $\mathrm{~N}$ & 28,3 & $\mathrm{~N}$ \\
\hline \multicolumn{8}{|c|}{ The Republic of Buryatia } \\
\hline 2.1 & 40 & & 70 & 95,1 & $\mathrm{C}$ & 94,2 & $\mathrm{C}$ \\
\hline 2.2 & 50 & & 70 & 83,3 & $\mathrm{C}$ & 79,1 & $\mathrm{C}$ \\
\hline \multicolumn{8}{|c|}{ Tyva Republic } \\
\hline 2.1 & 90 & $>90$ & & 97,2 & $\mathrm{PC}$ & 100 & $\mathrm{PC}$ \\
\hline 2.2 & 50 & & 70 & 36,3 & $\mathrm{~N}$ & 59,5 & $\mathrm{PC}$ \\
\hline \multicolumn{8}{|c|}{ Altai Republic } \\
\hline 2.1 & 40 & & 70 & 53,8 & $\mathrm{PC}$ & 43,8 & $\mathrm{PC}$ \\
\hline 2.2 & 50 & & 70 & 100 & $\mathrm{C}$ & 64,1 & $\mathrm{PC}$ \\
\hline
\end{tabular}

In the Republic of Buryatia and the Altai Territory, the share of coal exceeded in 2012-2016 - 90\%. The precrisis situation, with a share of the dominant resource, is observed in the Novosibirsk, Omsk regions, the Republic of Khakassia, Tyva, as well as in the Transbaikal
Territory and the Altai Republic. In Irkutsk, Kemerovo regions and the Krasnoyarsk Territory, the situation on this indicator can be considered acceptable, due to the dominance of own fuel and energy resources in these regions. At the same time, regarding the discussion of the threshold values of the indicators, the qualitative assessment of the "pre-crisis" in the self-reliant regions (belonging to group 1) indicates the desirability of greater species diversification of fuel and energy supply in order to increase the systems' readiness for potential changes in the structure of the country's TEBs and its regions for various reasons, including for reasons related to the prices of primary fuel and energy resources. According to indicator 2.2 (the share of the largest power plant in the installed electric capacity of the territory), the most acute situation is observed in the Republic of Buryatia (Gusinoozerskaya GRES - 79\% of the total installed capacity) and Khakassia (Sayano-Shushenskaya HPP - $89 \%$ of the total installed capacity). Since in the event of an accident, such a high share of a single source is very dangerous due to possible problems in the electricity supply of consumers. The situation in the Altai Republic has improved over this indicator in recent years, moving from crisis to pre-crisis by introducing new capacities and redistributing the load.

In the state of pre-crisis, i.e., where it is desirable to develop the growth trend of generating capacities in order to cover the growing demand for electric power, it is the Republic of Tyva (Mobile GTPP - 59\% of the installed capacity of the region).

Another important aspect affecting the provision of energy security in the regions is the state of the main production assets of the energy sector. The average data on the wear and tear of the basic production assets energy industries in the territories, correlated with the book value of these industries in these territories allow approximately to estimate the average wear and tear in the energy sector of the territories.

Analysis of the data in Table 4 shows that in recent years, the worsening of energy equipment in the Novosibirsk Region, the Altai Republic and the Altai Territory has worsened (and, most importantly, continues to deteriorate at a fairly rapid pace).

Table 4. Characteristics of the status of indicators in the territory of the subjects of the Siberian Federal District by the state block of the basic production assets of energy systems

\begin{tabular}{|c|c|c|c|c|c|c|}
\hline \multirow{2}{*}{$\begin{array}{c}\text { Indicator } \\
\text { (dimensio } \\
\mathrm{n}-\%)\end{array}$} & \begin{tabular}{c} 
The $\begin{array}{c}\text { Theshold } \\
\text { values of } \\
\text { the indicator }\end{array}$ \\
\cline { 2 - 7 }
\end{tabular} & $\begin{array}{c}\text { The meaning and status of } \\
\text { the indicator, year }\end{array}$ \\
\hline 1 & 2 & 3 & 4 & 5 & 6 & 7 \\
\hline 3.1 & 40 & 60 & C & 2012 & \multicolumn{2}{c|}{2016} \\
\hline 3.2 & 2 & 1 & 1,6 & $\mathrm{PC}$ & 1,7 & $\mathrm{PC}$ \\
\hline \multicolumn{7}{|c|}{ Kemerovo Region } \\
\hline 3.1 & 40 & 60 & 47,5 & $\mathrm{PC}$ & 43,7 & $\mathrm{PC}$ \\
\hline 3.2 & 2 & 1 & 3,7 & $\mathrm{~N}$ & 1,9 & $\mathrm{~N}$ \\
\hline
\end{tabular}




\begin{tabular}{|c|c|c|c|c|c|c|}
\hline \multicolumn{7}{|c|}{ Novosibirsk region } \\
\hline 3.1 & 40 & 60 & 55 & $\mathrm{PC}$ & 61 & $\mathrm{C}$ \\
\hline 3.2 & 2 & 1 & 1 & $\mathrm{C}$ & 0,7 & $\mathrm{C}$ \\
\hline \multicolumn{7}{|c|}{ Omsk Region } \\
\hline 3.1 & 40 & 60 & 38,3 & $\mathrm{~N}$ & 36,7 & $\mathrm{~N}$ \\
\hline 3.2 & 2 & 1 & 9 & $\mathrm{~N}$ & 7,3 & $\mathrm{~N}$ \\
\hline \multicolumn{7}{|c|}{ Tomsk Region } \\
\hline 3.1 & 40 & 60 & 33,6 & $\mathrm{~N}$ & 39,7 & $\mathrm{~N}$ \\
\hline 3.2 & 2 & 1 & 12,2 & $\mathrm{~N}$ & 0,9 & $\mathrm{C}$ \\
\hline \multicolumn{7}{|c|}{ Krasnoyarsk region } \\
\hline 3.1 & 40 & 60 & 44 & $\mathrm{PC}$ & 38 & $\mathrm{~N}$ \\
\hline 3.2 & 2 & 1 & 2,9 & $\mathrm{~N}$ & 4,9 & $\mathrm{~N}$ \\
\hline \multicolumn{7}{|c|}{ Irkutsk region } \\
\hline 3.1 & 40 & 60 & 54,2 & $\mathrm{PC}$ & 53,7 & $\mathrm{PC}$ \\
\hline 3.2 & 2 & 1 & 1,8 & $\mathrm{PC}$ & 0,6 & $\mathrm{C}$ \\
\hline \multicolumn{7}{|c|}{ The Republic of Khakassia } \\
\hline 3.1 & 40 & 60 & 39,5 & $\mathrm{~N}$ & 38,7 & $\mathrm{~N}$ \\
\hline 3.2 & 2 & 1 & 7,7 & $\mathrm{~N}$ & 4,4 & $\mathrm{~N}$ \\
\hline \multicolumn{7}{|c|}{ Transbaikal region } \\
\hline 3.1 & 40 & 60 & 48,3 & $\mathrm{PC}$ & 47,7 & $\mathrm{PC}$ \\
\hline 3.2 & 2 & 1 & 2,9 & $\mathrm{~N}$ & 3,9 & $\mathrm{~N}$ \\
\hline \multicolumn{7}{|c|}{ The Republic of Buryatia } \\
\hline 3.1 & 40 & 60 & 45,9 & $\mathrm{PC}$ & 43,4 & $\mathrm{PC}$ \\
\hline 3.2 & 2 & 1 & 2 & $\mathrm{PC}$ & 5 & $\mathrm{~N}$ \\
\hline \multicolumn{7}{|c|}{ Tyva Republic } \\
\hline 3.1 & 40 & 60 & 50,1 & $\mathrm{PC}$ & 58,4 & $\mathrm{PC}$ \\
\hline 3.2 & 2 & 1 & 29,2 & $\mathrm{~N}$ & 7,3 & $\mathrm{~N}$ \\
\hline \multicolumn{7}{|c|}{ Altai Republic } \\
\hline 3.1 & 40 & 60 & 62 & $\mathrm{C}$ & 70 & $\mathrm{C}$ \\
\hline 3.2 & 2 & 1 & 0 & $\mathrm{C}$ & 33,7 & $\mathrm{~N}$ \\
\hline
\end{tabular}

The situation on the average in the energy sectors and in most other districts of the district continues to deteriorate, while remaining in the middle of the precrisis range in such regions as Irkutsk Region, Republic of Tyva, Republic of Buryatia, Kemerovo Region. Positive trends by 2016 with the renewal and modernization of the basic production assets energy sector are observed in Khakassia, due to the active restoration and modernization of the Sayano-Shushenskaya HPP, as well as modernization at the Abakanskaya CHPP with the commissioning of two power units with a total capacity of $256 \mathrm{MW}$. In the Kemerovo Region, KuzbassEnergo carried out a major overhaul of 11 turbine units, and power units were put into operation at Novokuznetskaya GTPP. In the Omsk region and the Republic of Buryatia, acceptable indicators for the indicator are also associated with an active policy for capital repairs and reconstruction of power generating capacities. To a large extent, the value of this indicator is due to the commissioning of new capacities, major repairs and technical re-equipment of existing power generating sources. In the crisis situation in the aspect reflected by indicator 3.2 are: Novosibirsk, Tomsk, Irkutsk regions and the Republic of Altai, where for the analysis preceding the 5-year period there was insufficient commissioning of new capacities and practically no serious work was done to modernize the installed equipment, which in turn led to a decrease in the level of energy security of regions in the aspect described by this indicator.

Smaller inputs and some equipment upgrades were carried out in the Altai Republic and the Altai Territory (commissioning $130 \mathrm{MW}$ at Barnaulskaya CHP-2 in 2016), but in insufficient (in terms of energy security) volumes to reverse the negative trends with the aging of the basic production assets. As for the indicator of the renewal of power generating equipment in the Irkutsk Region and the Trans-Baikal Territory, there were not enough new power inputs.

In the Irkutsk region in 2012, a turbine unit with a capacity of $50 \mathrm{MW}$ was launched at Novo-Irkutsk TPP. In the Trans-Baikal Region, the commissioning of a hydroelectric unit at Kharanorskaya HPP in the same year, with a capacity of 225 MW. In addition, major repairs of equipment and reconstruction were carried out.

These actions brought the situation on this indicator in an acceptable state from the EB's position in the Trans-Baikal Territory, but they were insufficient for the withdrawal of the Irkutsk region from the crisis.

Above were presented and analyzed the values of the main indicators, which form the basis for an integrated assessment of the level of energy security in the territory of the subjects of the Siberian Federal District. To obtain such an assessment, an approach based on the convolution of indicator values was used, taking into account their specific weights. Qualitative characteristics of the state of all the indicators discussed in Table. 2-3, were collected according to the respective territories and processed according to a special methodology. As a result, a qualitative final assessment of the energy security status of the territories of the subjects of the Siberian Federal District was presented. 5.

Based on the analysis of data in Table 5, the best condition for energy security is observed in the Tomsk region and the Krasnoyarsk Territory. The level of energy security close to acceptable can be considered in the Kemerovo, Omsk, Irkutsk regions and the TransBaikal Territory. It is necessary to pay serious attention to indicators, whose values in these territories are located in the zones of "crisis" and "pre-crisis" values. This signals serious problems in the field of fuel and energy supply of territories in the part described by the values of the respective indicators. In addition, the negative state of the indicators characterizing the condition of the OPF and the renewal of energy in these territories is, above all, hindering the achievement of a better position.

The most acute situation with ensuring energy security should be noted in the Republic of Altai. Here, the crisis situation of most of the monitored indicators is evident, this concerns both the degree of the maximum electrical load and the share of the largest power generating source in the installed capacity in the territory, and the wear and tear of the energy sector. 
Table 5. Assessment of the qualitative state of certain regions of the Russian Federation

\begin{tabular}{|c|c|c|c|c|c|c|c|c|c|c|c|c|}
\hline \multirow{4}{*}{ Year } & \multicolumn{8}{|c|}{ The order numbers of the estimated ES indicators } & \multirow{2}{*}{\multicolumn{3}{|c|}{$\begin{array}{c}\text { The sum of the specific } \\
\text { weights by state } \\
\text { Boundaries of states }\end{array}$}} & \multirow{4}{*}{$\begin{array}{l}\text { Quality } \\
\text { condition } \\
\text { ES }\end{array}$} \\
\hline & 1.1 & 1.2 & 1.3 & 2.1 & 2.2 & 2.3 & 3.1 & 3.2 & & & & \\
\hline & \multicolumn{8}{|c|}{ Specific weights of indicators } & \multirow[b]{2}{*}{$\mathrm{C}$} & \multirow[b]{2}{*}{$\mathrm{PC}$} & \multirow[b]{2}{*}{$\mathrm{N}$} & \\
\hline & $\frac{\mathbb{d}}{0}$ & $\frac{\infty}{\stackrel{\infty}{0}}$ & $\frac{m}{0}$ & $\frac{\stackrel{ }{1}}{0}$ & $\begin{array}{l}\hat{0} \\
0 \\
0\end{array}$ & $\frac{R}{0}$ & $\frac{\widehat{N}}{0}$ & $\frac{\stackrel{\Xi}{0}}{0}$ & & & & \\
\hline 1 & 2 & 3 & 4 & 5 & 6 & 7 & 8 & 9 & 10 & 11 & 12 & 13 \\
\hline \multicolumn{13}{|c|}{ Altai region } \\
\hline 2012 & $\mathrm{~N}$ & $\mathrm{~N}$ & $\mathrm{C}$ & $\mathrm{C}$ & $\mathrm{N}$ & $\mathrm{N}$ & $\mathrm{PC}$ & $\mathrm{PC}$ & 0,253 & 0,256 & 0,491 & $\mathrm{PC}$ \\
\hline 2016 & $\mathrm{~N}$ & $\mathrm{~N}$ & $\mathrm{C}$ & $\mathrm{C}$ & $\mathrm{N}$ & $\mathrm{N}$ & $\mathrm{PC}$ & $\mathrm{PC}$ & 0,253 & 0,256 & 0,491 & $\mathrm{PC}$ \\
\hline \multicolumn{13}{|c|}{ Kemerovo Region } \\
\hline 2012 & $\mathrm{~N}$ & $\mathrm{~N}$ & $\mathrm{~N}$ & $\mathrm{~N}$ & $\mathrm{~N}$ & $\mathrm{~N}$ & $\mathrm{PC}$ & $\mathrm{N}$ & 0 & 0,127 & 0,873 & $\mathrm{~N}$ \\
\hline 2016 & $\mathrm{~N}$ & $\mathrm{~N}$ & $\mathrm{~N}$ & $\mathrm{~N}$ & $\mathrm{~N}$ & $\mathrm{~N}$ & $\mathrm{PC}$ & $\mathrm{N}$ & 0 & 0,127 & 0,873 & $\mathrm{~N}$ \\
\hline \multicolumn{13}{|c|}{ Novosibirsk region } \\
\hline 2012 & $\mathrm{~N}$ & $\mathrm{~N}$ & $\mathrm{PC}$ & $\mathrm{C}$ & $\mathrm{N}$ & $\mathrm{N}$ & $\mathrm{PC}$ & $\mathrm{C}$ & 0,249 & 0,260 & 0,491 & $\mathrm{PC}$ \\
\hline 2016 & $\mathrm{~N}$ & $\mathrm{~N}$ & $\mathrm{~N}$ & $\mathrm{C}$ & $\mathrm{N}$ & $\mathrm{N}$ & $\mathrm{C}$ & $\mathrm{C}$ & 0,376 & 0 & 0,624 & $\mathrm{PC}$ \\
\hline \multicolumn{13}{|c|}{ Omsk Region } \\
\hline 2012 & $\mathrm{~N}$ & $\mathrm{~N}$ & $\mathrm{~N}$ & $\mathrm{PC}$ & $\mathrm{N}$ & $\mathrm{N}$ & $\mathrm{N}$ & $\mathrm{N}$ & 0 & 0,120 & 0,880 & $\mathrm{~N}$ \\
\hline 2016 & $\mathrm{~N}$ & $\mathrm{~N}$ & $\mathrm{PC}$ & $\mathrm{PC}$ & $\mathrm{N}$ & $\mathrm{N}$ & $\mathrm{N}$ & $\mathrm{N}$ & 0 & 0,253 & 0,747 & $\mathrm{~N}$ \\
\hline \multicolumn{13}{|c|}{ Tomsk Region } \\
\hline 2012 & $\mathrm{~N}$ & $\mathrm{~N}$ & $\mathrm{~N}$ & $\mathrm{~N}$ & $\mathrm{~N}$ & $\mathrm{~N}$ & $\mathrm{~N}$ & $\mathrm{~N}$ & 0 & 0 & 1 & $\mathrm{~N}$ \\
\hline 2016 & $\mathrm{~N}$ & $\mathrm{~N}$ & $\mathrm{~N}$ & $\mathrm{~N}$ & $\mathrm{~N}$ & $\mathrm{~N}$ & $\mathrm{~N}$ & $\mathrm{C}$ & 0,129 & 0 & 0,871 & $\mathrm{~N}$ \\
\hline \multicolumn{13}{|c|}{ Krasnoyarsk region } \\
\hline 2012 & $\mathrm{~N}$ & $\mathrm{~N}$ & $\mathrm{~N}$ & $\mathrm{~N}$ & $\mathrm{~N}$ & $\mathrm{~N}$ & $\mathrm{PC}$ & $\mathrm{N}$ & 0 & 0,127 & 0,873 & $\mathrm{~N}$ \\
\hline 2016 & $\mathrm{~N}$ & $\mathrm{~N}$ & $\mathrm{~N}$ & $\mathrm{~N}$ & $\mathrm{~N}$ & $\mathrm{~N}$ & $\mathrm{~N}$ & $\mathrm{~N}$ & 0 & 0 & 1 & $\mathrm{~N}$ \\
\hline \multicolumn{13}{|c|}{ Irkutsk region } \\
\hline 2012 & $\mathrm{~N}$ & $\mathrm{~N}$ & $\mathrm{~N}$ & $\mathrm{~N}$ & $\mathrm{~N}$ & $\mathrm{~N}$ & $\mathrm{PC}$ & $\mathrm{PC}$ & 0 & 0,256 & 0,744 & $\mathrm{~N}$ \\
\hline 2016 & $\mathrm{~N}$ & $\mathrm{~N}$ & $\mathrm{~N}$ & $\mathrm{~N}$ & $\mathrm{~N}$ & $\mathrm{~N}$ & $\mathrm{PC}$ & $\mathrm{C}$ & 0,129 & 0,127 & 0,744 & $\mathrm{~N}$ \\
\hline \multicolumn{13}{|c|}{ The Republic of Khakassia } \\
\hline 2012 & $\mathrm{~N}$ & $\mathrm{~N}$ & $\mathrm{~N}$ & $\mathrm{PC}$ & $\mathrm{C}$ & $\mathrm{N}$ & $\mathrm{N}$ & $\mathrm{N}$ & 0,079 & 0,120 & 0,801 & $\mathrm{~N}$ \\
\hline 2016 & $\mathrm{~N}$ & $\mathrm{~N}$ & $\mathrm{~N}$ & $\mathrm{PC}$ & $\mathrm{C}$ & $\mathrm{N}$ & $\mathrm{N}$ & $\mathrm{N}$ & 0,079 & 0,120 & 0,801 & $\mathrm{~N}$ \\
\hline \multicolumn{13}{|c|}{ Transbaikal region } \\
\hline 2012 & $\mathrm{~N}$ & $\mathrm{~N}$ & $\mathrm{~N}$ & $\mathrm{PC}$ & $\mathrm{N}$ & $\mathrm{N}$ & $\mathrm{PC}$ & $\mathrm{N}$ & 0 & 0,247 & 0,753 & $\mathrm{~N}$ \\
\hline 2016 & $\mathrm{~N}$ & $\mathrm{~N}$ & $\mathrm{~N}$ & $\mathrm{PC}$ & $\mathrm{N}$ & $\mathrm{N}$ & $\mathrm{PC}$ & $\mathrm{N}$ & 0 & 0,247 & 0,753 & $\mathrm{~N}$ \\
\hline \multicolumn{13}{|c|}{ The Republic of Buryatia } \\
\hline 2012 & $\mathrm{~N}$ & $\mathrm{~N}$ & $\mathrm{PC}$ & $\mathrm{C}$ & $\mathrm{C}$ & $\mathrm{N}$ & $\mathrm{PC}$ & $\mathrm{PC}$ & 0,199 & 0,389 & 0,412 & $\mathrm{PC}$ \\
\hline 2016 & $\mathrm{~N}$ & $\mathrm{~N}$ & $\mathrm{~N}$ & $\mathrm{C}$ & $\mathrm{C}$ & $\mathrm{N}$ & $\mathrm{PC}$ & $\mathrm{N}$ & 0,199 & 0,129 & 0,674 & $\mathrm{PC}$ \\
\hline \multicolumn{13}{|c|}{ Tyva Republic } \\
\hline 2012 & $\mathrm{PC}$ & $\mathrm{C}$ & $\mathrm{N}$ & $\mathrm{PC}$ & $\mathrm{N}$ & $\mathrm{N}$ & $\mathrm{PC}$ & $\mathrm{N}$ & 0,138 & 0,351 & 0,511 & $\mathrm{PC}$ \\
\hline 2016 & $\mathrm{~N}$ & $\mathrm{C}$ & $\mathrm{N}$ & $\mathrm{PC}$ & $\mathrm{PC}$ & $\mathrm{N}$ & $\mathrm{PC}$ & $\mathrm{N}$ & 0,242 & 0,326 & 0,432 & $\mathrm{PC}$ \\
\hline \multicolumn{13}{|c|}{ Altai Republic } \\
\hline 2012 & $\mathrm{C}$ & $\mathrm{C}$ & $\mathrm{C}$ & $\mathrm{PC}$ & $\mathrm{C}$ & $\mathrm{C}$ & $\mathrm{C}$ & $\mathrm{C}$ & 0,880 & 0,120 & 0 & $\mathrm{C}$ \\
\hline 2016 & $\mathrm{C}$ & $\mathrm{C}$ & $\mathrm{C}$ & $\mathrm{PC}$ & $\mathrm{PC}$ & $\mathrm{C}$ & $\mathrm{C}$ & $\mathrm{N}$ & 0,672 & 0,199 & 0,129 & $\mathrm{C}$ \\
\hline
\end{tabular}

\section{Conclusion}

Analysis of the dynamics of qualitative assessments of energy security in the regions and quantitative indicators of the weights of indicators that are in different states from 2012 to 2016 allows to draw a conclusion that the situation with ensuring energy security during this period on average had positive trends: for all subjects of the Siberian Federal District, with the exception of the Republic of Altai.

\section{References}

1. N. Pyatkova, S. Senderov, M. Cheltsov, “Application of a two-level technology for research in solving energy security problems, " Izvestiya RAN, Power Engineering, 6, (2000)

2. V. Bushuyev, N. Voropai, A. Masterpanov, Yu. Shafranik, "Energy security of Russia," Novosibirsk, Science, Siberian Publishing Company RAS (1998) 
3. S. Senderov, N. Pyatkova, V. Rabchuk, G. Slavin, S. Vorobev, E. Smirnova, "Methodology for monitoring the state of energy security of Russia at the regional level," ISEM SB RAS, (2014)

4. S. Senderov, "Assessment of the level of energy security in the regions of Russia and the basic principles for the establishment of a system for monitoring energy security," Safety of objects of the fuel and energy complex, 1,(2012)

5. Statistical form of Rosstat, "Information on balances, receipt and consumption of fuel and heat, collection and use of used oil products", (2012-2016)

6. Statistical form of Rosstat, "Information on the use of fuel and energy resources”, (2012-2016)

7. Statistical form of Rosstat, "Technical and economic indicators of power plants, district boilers", (20122016). 